Hilditch, T. P. (1940). The Chemical Constitution of Natural Fats. London: Chapman and Hall Ltd. Lambert, M. R., Jacobson, N. L., Allen, R. S. \& Zaletel, J. H. (1954). F. Nutr. 52, 259.

Mattil, K. F. (1946). Oil E Soap, 23, 344.

Maynard, L. A. (1947). Animal Nutrition, 2nd ed. New York and London: McGraw-Hill Book Co. Inc. Raven, A. M. \& Robinson, K. L. (1958). Brit. F. Nutr. 12, 469.

Smith, R. H. (1957). Biochem. F. 67, 472 .

\title{
Diet in pregnancy
}

\section{2.* Assessment of the nutritive value of diets, especially in relation to differences between social classes}

\author{
BY A. M. THOMSON \\ Obstetric Medicine Research Unit (Medical Research Council), \\ University of Aberdeen
}

(Received 17 September 1958)

The first paper in this series (Thomson, 1958) described and discussed the methods used in a dietary survey of 489 Aberdeen women pregnant for the first time. Three social classes were distinguished according to the occupations of the husbands, as follows: class A, 'white-collar'; class B, skilled manual; class C, semi-skilled and unskilled. These classes correspond, respectively, to the Registrar-General's social classes I and II, III and IV and V, modified so that non-manual workers in Class III are included within classes I and II. Direct comparison of nutrient intake levels with the summary of allowances recommended for late pregnancy by the British Medical Association: Committee on Nutrition (1950) showed that many diets in all classes were substandard in one or more respects, the proportion rising as social status decreased.

A comparison of this kind is superficial and an inference that many diets were inadequate to support normal pregnancy may not be justified, even if the standards adopted are acceptable. A low calorie intake must be associated with a low intake of protein or fat or carbohydrate, or of any combination of these, and the intakes of many other nutrients are likely to be low also. At least part of the social gradient in the average nutritive value of diets must therefore be simply a reflexion of the social gradient in calorie intakes. It in turn may be determined in part by the well-known fact that average body size decreases with diminishing social status. Finally, since the requirement for some nutrients depends on energy metabolism, the adequacy of the intake of these depends to some extent upon the calorie value of the diet.

Two main problems will be considered in this paper : first, the extent to which intakes of calories and of the various nutrients are interdependent; and, second, the adequacy of the Aberdeen diets when variations of calorie intake are taken into account.

* Paper no. I: Brit. F. Nutr. (1958), 12, 446. 


\section{METHOD}

The methods used in the Aberdeen dietary survey, made in the years 1950-3, have already been described (Thomson, 1958). The correlations and regressions described below may be peculiar to this survey, and therefore certain comparisons were made with the data of the following two surveys, for which sufficiently detailed records are available:

(I) The McCance survey (McCance, Widdowson \& Verdon-Roe, 1938). It measured the diets of 120 pregnant women in various parts of England and Wales during a period of severe industrial depression. The husbands of many of the subjects were unemployed.

(2) The Carnegie survey (Rowett Research Institute, 1955). This was a survey of family diets made in several areas of England and Scotland in 1938-9. Original records for 437 families were kindly made available by the Director of the Rowett Research Institute.

Quantities of food were estimated by weighing in all three surveys. The foodanalysis tables used in each survey were different, so that similarities between the data are not likely to be accentuated by a common analytical procedure.

\section{RESULTS AND DISCUSSION}

\section{Correlations between nutrients}

Surprisingly, no comprehensive investigations of the correlations between the nutrient contents of ordinary diets seem to have been reported previously. To be sure, there are numerous references in the literature to correlations between energy intake and intake of single nutrients, such as protein. For example, Cuthbertson (1940-1) noted that the percentage of calories derived from protein in mixed diets ranges from 9.5 to 17.0 ; in diets chiefly of plant origin from 8.5 to 14.5 ; and in diets chiefly of animal origin, e.g. Eskimo diets, up to 44 . Such figures represent extremes. Dole (I957) found from the statistics of food consumption in thirty-two nations that in most groups protein provides $10-13 \%$ of the calories.

The diagonal in Table $\mathrm{I}$ gives the mean intakes and standard deviations found in the Aberdeen survey.* The data in the cells above the diagonal are also derived from the Aberdeen survey: in each cell, the top figure $(r)$ is the coefficient of correlation between pairs of nutrients; the middle figure $(b)$ is the coefficient of regression of the variable in a given column on the variable in a given row; the lowest figure (S.E.) allows us to gauge the standard error of the estimate of the mean of a variable in a given column when the value of the variable in a given row is known.

All the correlations and regressions in the upper part of Table $\mathrm{I}$ are highly significant in the statistical sense but, as the sizes of the standard errors indicate, the regressions are of limited assistance in estimating the intake by an individual of a given nutrient

* The means shown are not representative of all primigravidae in Aberdeen, because the sample was weighted by the inclusion of a disproportionate number of subjects in social class $\mathrm{C}$. Some of the poorest diets may not have been included owing to failure of the survey technique with unintelligent and uncooperative subjects, thus causing a bias in the opposite direction. For details see Thomson (I958). 
胥

昰高

:

כ

은

可.

들

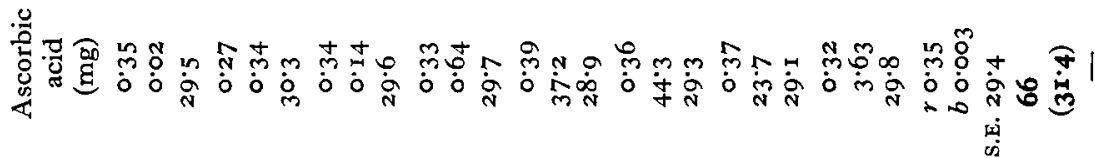

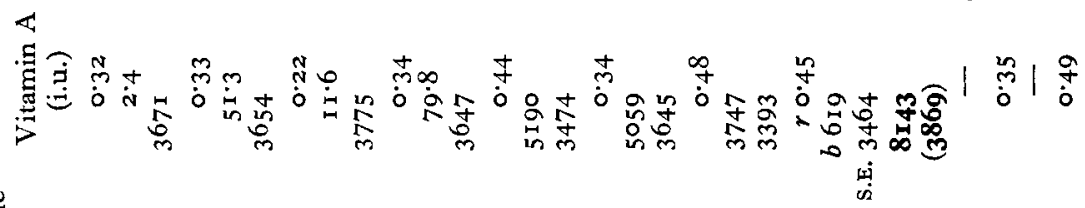

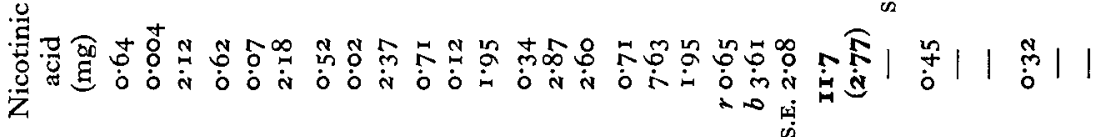

응

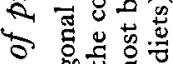

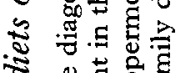

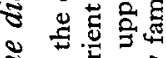

₹

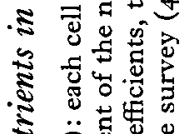

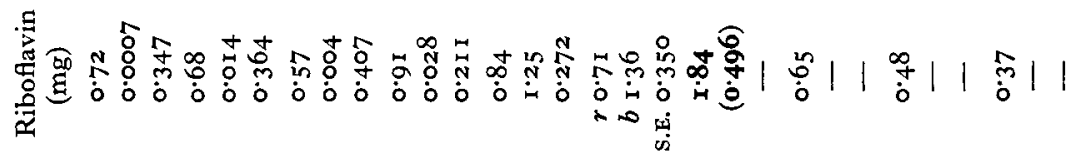

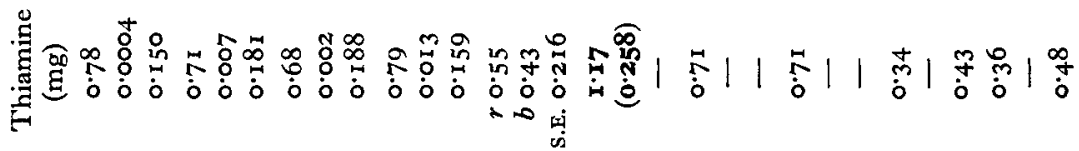

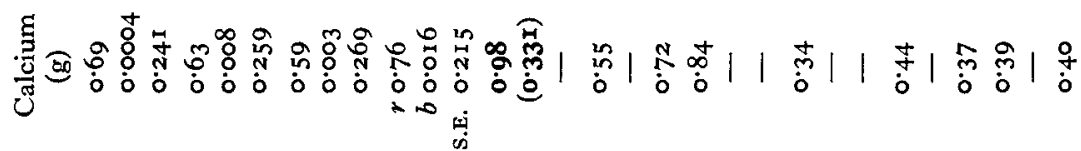

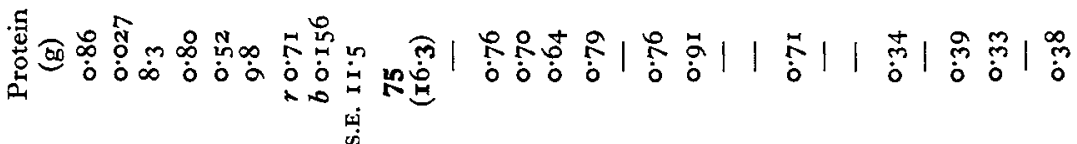

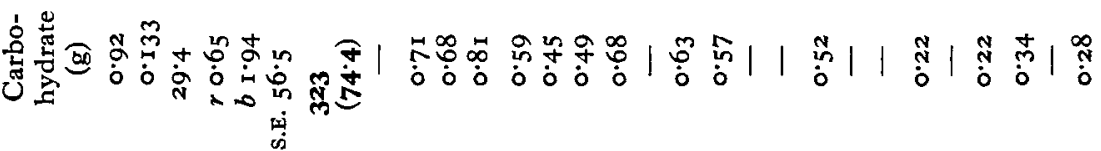

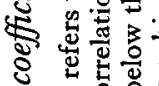

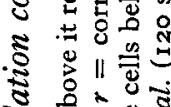

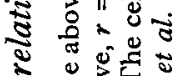

डิ

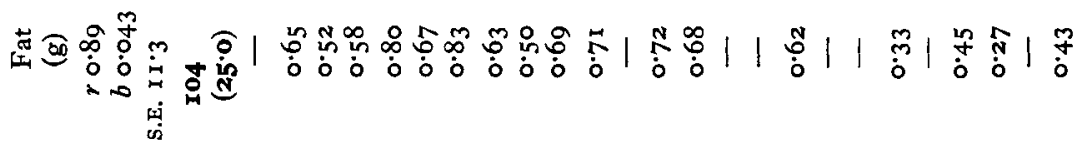

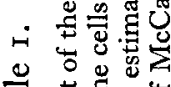

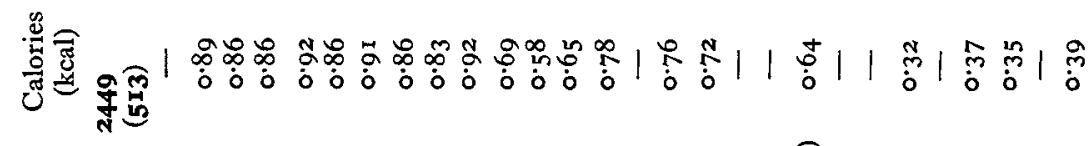

藏

政

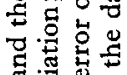

可溇

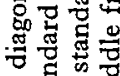

웡

这

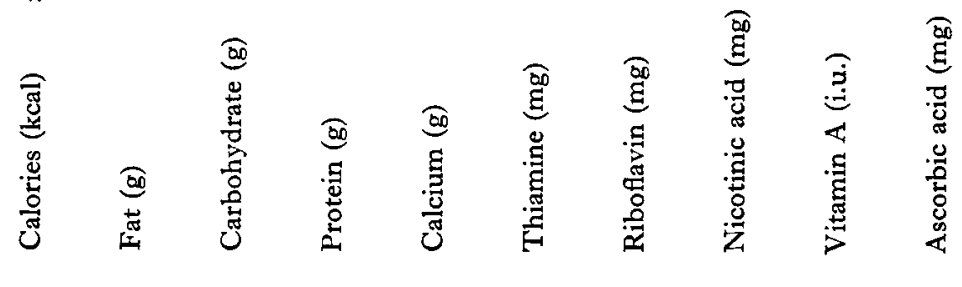


when the intake of its 'pair' is known. For example, if the calorie intake of an individual is known, the estimated protein intake may easily be in error by $8 \mathrm{~g}$ or more.

The part of Table $\mathrm{r}$ below the diagonal compares the correlation coefficients for the Aberdeen data with those for the McCance and the Carnegie surveys. There are several gaps, because the McCance survey data do not include vitamins and the Carnegie survey data do not include riboflavin and nicotinic acid. The comparisons available, however, show a striking degree of agreement, and it seems safe to generalize fairly widely from the Aberdeen data alone, at least so far as dietary habits in Britain are concerned.

To summarize, the intakes of calories, fat, protein, carbohydrate, thiamine and riboflavin are all highly intercorrelated, with coefficients mostly above $0 \cdot 7$. The intakes of calcium and nicotinic acid are both highly correlated with those of calories, fat, protein and riboflavin; that of nicotinic acid is also highly correlated with that of thiamine. Correlations of vitamin A and ascorbic acid with each other and with other nutrients are of a lower order.

Such correlations show that, with dietary-survey data, the intakes of single nutrients should not be interpreted in isolation, as though they were the independent variables in strictly controlled feeding experiments. Yet there are abundant discussions in the literature on the significance for health of, for example, protein intakes without reference to calorie intakes. In the surveys now under discussion, a low-protein diet was, with rare exceptions only, a low-calorie diet.

\section{Social class and correlations between nutrients}

The survey data were further explored after dividing them into social-class groups. The social classification used in the Aberdeen survey has been summarized above. We classified the data of the McCance survey on the same occupational basis. The Carnegie data were classified into three groups on the basis of food expenditure/head/ week, occupational data not being available. For each survey, separate regressions were calculated for the three groups and tested statistically to find if there was a significant difference in the slopes of, or in the distances between, the three regression lines.

Sources of energy. In all three surveys, the regressions of protein intake on calorie intake appeared to be parallel; that is, the change in protein intake per unit change of calorie intake was similar in each social class. The distances between the regression lines were not significant in the Aberdeen data, and just significant in the McCance data; in both these surveys the use of an overall regression does not distort unduly the slope of the regression line for any one social group. (If the social-class regression lines were parallel but widely separated, an overall regression line would be steeper than the line for any one social class.) The distances between the regression lines in the Carnegie data could not be assessed reliably, because the means for each food-expenditure group are so widely different that the extremes overlap only slightly.

In all three surveys, the lowest social class had the highest regression of carbohydrate on calories and the lowest of fat on calories. The differences of slopes between social classes attain statistical significance in the Carnegie survey only but, taken as a whole, the findings indicate that the regression lines for the three classes are not parallel. 
The proportion of calories derived from carbohydrate tends to increase more rapidly with a rising calorie intake in the lower than in the higher social classes, and the reverse is true of the association between fat intake and calorie intake. The relative changes are, however, so small as to be of little practical significance.

Table 2 includes the observed mean intakes by social classes of protein, carbohydrate and fat in the Aberdeen survey, and the means after standardizing for interclass differences of calorie intake. The adjustment almost eliminates the social-class gradient in the observed values for these nutrients. In the data of the McCance survey significant differences remain between the adjusted means. Reliable conclusions cannot be drawn from the Carnegie survey data for the reason given above.

Other nutrients. Table 2 also includes observed and adjusted means for nutrients other than protein, carbohydrate and fat. Standardization by calorie intake leaves a diminished but appreciable social-class gradient in intakes of calcium and ascorbic acid, removes most of the gradient in riboflavin intake, and actually reverses the gradient in thiamine and nicotinic-acid intakes.

\section{Body size and calorie intake}

All the information which follows relates to the Aberdeen survey. Table 3 shows that subjects in class A were on the average $\mathrm{r} \cdot 4$ in. $(3.5 \mathrm{~cm})$ taller and $8.8 \mathrm{lb}(4.0 \mathrm{~kg})$ heavier than subjects in class $\mathrm{C}$, class $\mathrm{B}$ being intermediate. The weights are those recorded at the time of the dietary survey, mostly in the 7 th month of pregnancy. These weights include water stored during pregnancy, the amount of which varies greatly from subject to subject; but this variation probably does not matter in this context, since an analysis of several thousand hospital records showed that the average amount of weight gained during pregnancy differs little between social classes in primigravidae (Thomson \& Billewicz, 1957).

Calculation of the multiple regression of calorie intake on the weight and height of subjects, ${ }^{*}$ and an analysis of variance of calorie intake showed that, in each social class, weight and height add significantly to the 'explained' sum of squares of calorie intakes. Although the regression planes for each of the three social classes may be regarded as parallel to each other, the distances between the planes are highly significant.

The differences of calorie intake between social classes thus cannot be wholly explained by differences of height and weight. Though the social-class gradient is appreciably diminished by adjustment for height and weight, a mean difference of about $200 \mathrm{kcal}$ daily remains between class $\mathrm{A}$ and class $\mathrm{C}$. It is not possible, from these survey data alone, to account for this residual difference of calorie intake, but most of it was probably due to differences of activity. That is, activity tended to diminish with declining social status. We have no direct measure of activity, but proportionately more subjects in the lower social classes were sharing houses with relatives, who did much of the housework; also, domestic standards tended to be less exacting. Very few subjects in any class had paid domestic help, and at the time of the dietary survey

* For all social classes together, the multiple correlation coefficient was $r=0.28$; and $r_{\mathrm{kcal} \text {.H }}=0.236$, $r_{\text {kcal.Wt }}=0.22 \mathrm{I}, r_{\mathrm{Wt} . \mathrm{Ht}}=0.555$. 
Vol. I3

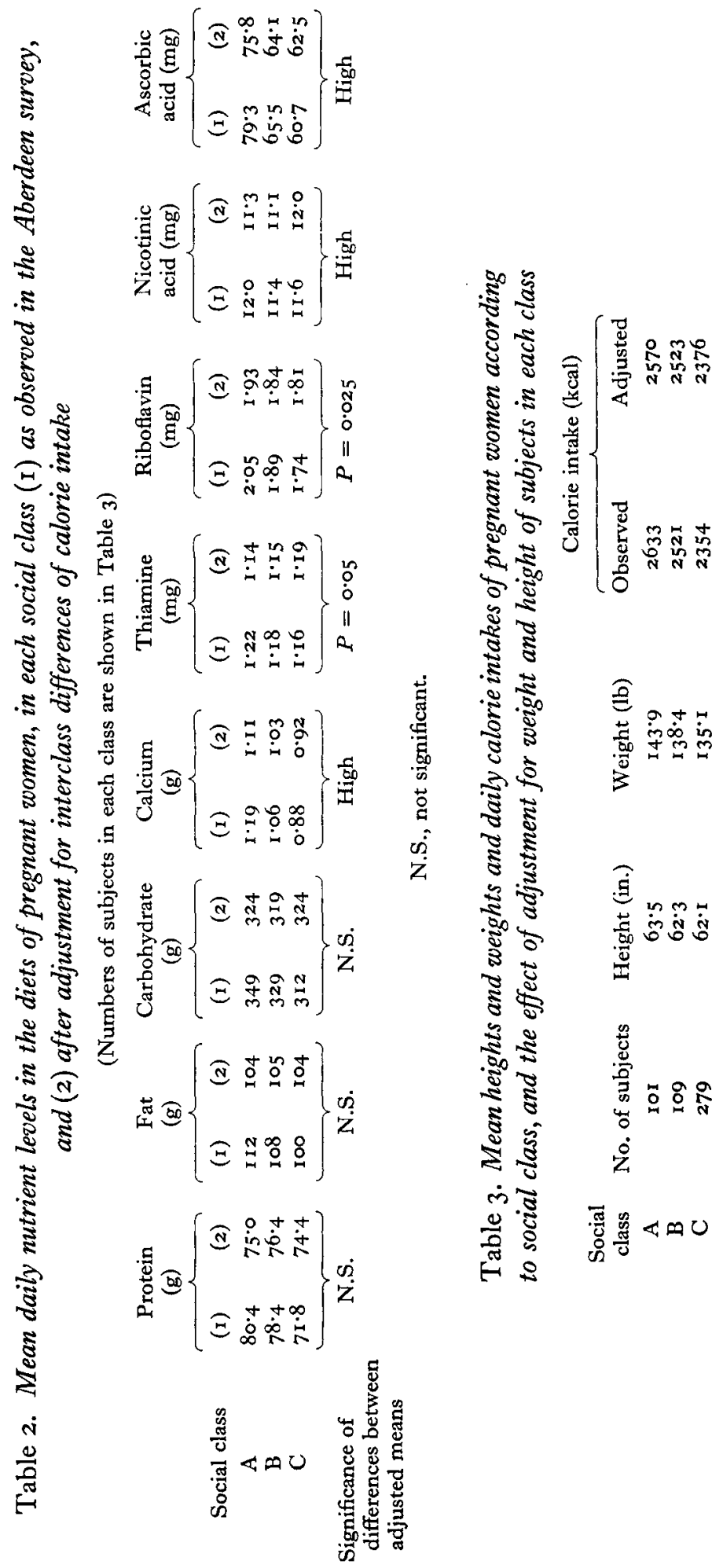


nearly all of them had stopped doing paid work themselves. The difference of calorie intake is not likely to be accounted for by differences of weight gained during pregnancy. As mentioned above, previous investigation showed that primigravidae in the upper social classes do not gain appreciably more weight than those in the lower classes (Thomson \& Billewicz, I957); the weight records of the dietary-survey subjects are in accord.

It remains to be shown whether the wide range of calorie intakes which is present in all social classes is associated with differing levels of health. As previously reported (Thomson, 1958), the lower and upper quartiles in social class A were about 2300 and $2900 \mathrm{kcal} / \mathrm{day}$; in social class $\mathrm{C}, 2000$ and 2700 . It is not likely that such wide ranges can be wholly attributed to differences of activity, together with differences of body size. The influence of calorie intake on the amount of weight gained during pregnancy, and its possible relationship with incidence of pre-eclampsia and other abnormalities, will be discussed in a further paper.

\section{Protein, fat and carbohydrate}

The mean intakes of protein in social classes A, B and C were, respectively, 8o, 78 and $72 \mathrm{~g}$; after adjustment for interclass differences of calorie intake they were 75 , 76 and $74 \mathrm{~g}$ (Table 2). The first part of Table 4 shows the average proportions of calories derived from protein, fat and carbohydrate in each class. The differences between classes are negligible. But the second part of Table 4 shows that the similarity is to some extent superficial. When the data in each class are broken down by the calorie values of the diets, it becomes obvious, in classes $B$ and $C$ at least, that with decreasing calorie intake the contribution of protein to calories tended to increase and that of carbohydrate to diminish. In other words, larger diets contained, on an average, relatively more carbohydrate and relatively less protein. The trends are, however, slight, and in one subgroup only was the average contribution of protein to calories less than $12 \%$, namely, social class $\mathrm{C}$ diets with more than $2700 \mathrm{kcal}$. On the other hand, none of the means for protein in Table 4 attains $13 \%$.

Table 5 shows the distribution within social classes of the percentages of calories derived from protein. The differences between classes are slight.

Table 6 shows the contribution of animal protein to the total protein intake. As social class declines, the average proportion of animal protein becomes less, but only from $57 \cdot 5$ to $56 \cdot 0 \%$.

It therefore appears that the reduction of average energy intake with diminishing social status was not accompanied by a disproportionate reduction of intake of protein. Furthermore, the ratio of animal protein to total protein was similar at each social level, and it would not be correct to assume that diets of low energy value, and hence of low protein content, contained more protein of inferior nutritive quality. Only 24 out of the 489 diets were found to provide less than $10 \%$ of calories in the form of protein, confirming Leitch's (I94I-2) statement that 'unless the diet contains a very high proportion of sugar, highly processed cereals and fat, it will be difficult to plan a diet containing less than to per cent. of its calories as protein'. The reason, of course, is that few foods other than those mentioned do not provide at least $10 \%$ of their 
calorie value in the form of protein. In all classes, about $\mathrm{II} \%$ of subjects were taking diets in which protein provided at least $14 \%$ of the calories, that is, the optimum amount of protein for pregnant women, according to the recommendation of the British Medical Association: Committee on Nutrition (1950). Well over half were taking the amount recommended for non-pregnant adults, I I \% of the calories provided in the form of protein. These standards may tentatively be regarded as optima which include a margin for safety. The minimum physiological requirement for protein remains undecided, but is certainly much lower. It seems reasonable to conclude that

Table 4. Mean percentages of calories derived from protein, fat and carbohydrate in the diets of pregnant women

\begin{tabular}{|c|c|c|c|c|}
\hline \multirow[b]{3}{*}{ Social class: A } & \multirow[b]{2}{*}{ No. of subjects } & \multicolumn{3}{|c|}{ Calories derived from } \\
\hline & & Protein & Fat & Carbohydrate \\
\hline & IOI & $12 \cdot 2$ & $38 \cdot 5$ & $49 \cdot 3$ \\
\hline B & 109 & 12.5 & $38 \cdot 7$ & $48 \cdot 8$ \\
\hline $\mathrm{C}$ & 279 & $12 \cdot 3$ & $3^{8} \cdot 3$ & $49 \cdot 4$ \\
\hline \multicolumn{5}{|c|}{ Social class A } \\
\hline \multicolumn{5}{|c|}{ Daily calorie intake (kcal) } \\
\hline 2700 and over & 39 & $12 \cdot 2$ & $38 \cdot 4$ & $49 \cdot 4$ \\
\hline $2300-2700$ & 36 & $12 \cdot 0$ & $37 \cdot 8$ & $50 \cdot 2$ \\
\hline Under 2300 & 26 & $12 \cdot 5$ & $37 \cdot 9$ & $49 \cdot 6$ \\
\hline \multicolumn{5}{|c|}{ Social class B } \\
\hline 2700 and over & 35 & $12 \cdot 0$ & $38 \cdot 7$ & $49 \cdot 3$ \\
\hline $2300-2700$ & 38 & $12 \cdot 6$ & $38 \cdot 7$ & $48 \cdot 7$ \\
\hline Under 2300 & 36 & $12 \cdot 9$ & $38 \cdot 7$ & $48 \cdot 4$ \\
\hline \multicolumn{5}{|c|}{ Social class $\mathrm{C}$} \\
\hline 2700 and over & 59 & $11 \cdot 7$ & $3^{8 \cdot 1} \cdot$ & $50 \cdot 2$ \\
\hline $2300-2700$ & 86 & $12 \cdot 2$ & $37 \cdot 9$ & $49 \cdot 9$ \\
\hline Under 2300 & 134 & $12 \cdot 6$ & 38.6 & 48.8 \\
\hline
\end{tabular}

Table 5. Distribution of percentages of calories derived from protein in the diets of pregnant women

Percentage of
calories derived
from protein
14 and over
I $2-14$
I0-12
Under 10
Total

\begin{tabular}{|c|c|c|}
\hline \multicolumn{3}{|c|}{ Social class } \\
\hline A & $\mathrm{B}$ & $\mathrm{C}$ \\
\hline I0.9 (I I ) & II $\cdot O(I 2)$ & $10.8(30)$ \\
\hline $40 \cdot 6(4 I)$ & $52 \cdot 3(57)$ & $45.5(127)$ \\
\hline $42 \cdot 6(43)$ & $36 \cdot 7(40)$ & $37.3(104)$ \\
\hline $5 \cdot 9(6)$ & - & $6 \cdot 4(18)$ \\
\hline $100 \quad$ (IOI) & roo (I09) & Ioo $(279)$ \\
\hline
\end{tabular}

Table 6. Mean values with their standard deviations for daily intakes of animal protein by pregnant women according to social class, expressed in $g$ and as a percentage of total protein intake

Total protein (g)

Animal protein (g)

Animal protein as percentage of total protein

\begin{tabular}{lll}
\multicolumn{3}{c}{ Social class } \\
\multicolumn{1}{c}{ B } & \multicolumn{1}{c}{ C } \\
$80 \cdot 4 \pm 17 \cdot 22$ & $78 \cdot 4 \pm 13 \cdot 34$ & $71 \cdot 8 \pm 15 \cdot 72$ \\
$46 \cdot 7 \pm 13 \cdot 34$ & $44 \cdot 3 \pm 11 \cdot 17$ & $40 \cdot 4 \pm 11 \cdot 75$ \\
$57 \cdot 5$ & $56 \cdot 2$ & $56 \cdot 0$
\end{tabular}


deficiency of protein of a degree likely to cause obvious ill-health during pregnancy was certainly uncommon, and possibly non-existent, in the Aberdeen diets.

\section{Calcium}

The mean intakes of calcium were $\mathrm{r} \cdot \mathrm{I} 9, \mathrm{I} \cdot 06$ and $0.88 \mathrm{~g}$ daily in social classes $\mathrm{A}, \mathrm{B}$ and $\mathrm{C}$, respectively. After adjustment for social-class differences of calorie intake, the mean intakes were $\mathrm{I} \cdot \mathrm{I}, \mathrm{I} \cdot 03$ and $0.92 \mathrm{~g}$, respectively (Table 2). Table 7 shows that the calcium intake/rooo kcal in each social class does not vary systematically with the calorie value of the diet, and the relatively low intake of calcium in social class $\mathrm{C}$ exists at all levels of calorie intake.

Table 7. Mean daily calcium intakes of pregnant women ( $\mathrm{g} / \mathrm{I} 000 \mathrm{kcal})$ according to social class and calorie value of the diets

$\begin{array}{lccc}\begin{array}{c}\text { Daily calorie intake } \\ \text { (kcal) }\end{array} & \mathrm{A} & \mathrm{B} & \mathrm{C} \\ \text { 2700 and over } & 0.46 & 0.40 & 0.37 \\ \text { 2300-2700 } & 0.45 & 0.44 & 0.38 \\ \text { Under 2300 } & 0.45 & 0.42 & 0.37 \\ \text { All } & 0.45 & 0.42 & 0.37\end{array}$

The social-class gradient in the intakes of calcium is thus by no means accounted for by the gradient in calorie intake; this situation is perhaps to be expected since the main source of calcium in the diet is milk, which provides a variable but generally small proportion of the total calorie value of diets. Few of our subjects took the amount of calcium recommended by the British Medical Association: Committee on Nutrition (1950) for late pregnancy, I.5 g daily. This recommendation undoubtedly provides a large margin of safety, but if it is adopted as a standard, $83 \%$ of the diets in class A provided insufficient calcium, the percentage rising to 96 in class C. A recent estimate by Leitch \& Aitken (1959) is based on the maintenance requirement of a nonpregnant adult plus an allowance for the calcification of the foetal skeleton, and assumes $30 \%$ utilization of the calcium in food. The requirement estimated on this basis is $\mathrm{I} \cdot 2 \mathrm{~g}$ daily. The authors say that 'Less will probably suffice, since it seems possible that the whole is not supplied from current intake and, even if it is, utilization may well be much better than 30 per cent.' On this lower standard, $\mathrm{I} \cdot 2 \mathrm{~g}$ daily, about half the women in class $\mathrm{A}$, and more than three-quarters of those in class $\mathrm{C}$, were taking insufficient calcium. However, the maternal skeleton is likely to contain about forty times as much calcium as that of the newborn infant, so that any drain on the maternal reserves of calcium during a single pregnancy will be relatively small. Deficiency of calcium in the diet is therefore not likely to harm the mother or the foetus immediately. Clinical evidence of deficiency may arise if a relatively slight drain upon calcium reserves during a first pregnancy is increased during lactation and repeated in subsequent pregnancies and lactations.

\section{Thiamine}

This vitamin is specifically concerned in the metabolism of carbohydrate, and it is now generally accepted that its requirement is best expressed in relation to the energy in the diet provided by protein and carbohydrate, the non-fat calories (N.F.C.). 
Frequently it is convenient to express the thiamine requirement in relation to the total energy value of the diet, in which event the proportion of calories derived from fat should be stated. The British Medical Association: Committee on Nutrition (1950) recommended that the diets of pregnant women should contain $0.4 \mathrm{mg}$ thiamine/rooo kcal, on the assumption that fat accounts for $25-30 \%$ of the total calories, or $0.6 \mathrm{mg} / \mathrm{rooo}$ N.F.C. (kcal). As Table 4 shows, in our subjects fat provided about $38 \%$ of the total calories, and a requirement of $0.4 \mathrm{mg}$ thiamine/rooo total kcal may be unnecessarily high. Subjects in social classes A, B and C had mean intakes, respectively, of $\mathrm{x} \cdot 22, \mathrm{I} \cdot \mathrm{I} 8$ and $\mathrm{x} \cdot \mathrm{I} 6 \mathrm{mg}$ thiamine daily; and in each class $\mathrm{I} 2,9$ and $7 \%$ took less than $0.4 \mathrm{mg} / \mathrm{ro00} \mathrm{kcal}$, and 8,5 and $3 \%$ less than $0.6 \mathrm{mg} / \mathrm{r} 000$ N.F.C. Table 8 shows that the mean intakes per $1000 \mathrm{kcal}$ and per 1000 N.F.c. increased with diminishing social status. This relationship remains true at each level of calorie intake. It also appears that within each social class the intake of thiamine becomes relatively greater as the total energy intake and the N.F.c. intake diminish.

These findings are discussed below, together with those for nicotinic acid.

Table 8. Mean daily intakes of thiamine by pregnant women ( $\mathrm{mg} / \mathrm{1000} \mathrm{kcal}$ and $\mathrm{mg} /$ I000 N.F.C.*) according to social class, and total calorie and non-fat calorie values of the diets

Daily calorie intake (kcal)

2700 and over 2300-2700 Under 2300 All

2700 and over $2300-2700$ Under 2300 All

\begin{tabular}{lll}
\multicolumn{3}{c}{ Social class } \\
$\overbrace{\mathrm{A}} \mathrm{B}$ & $\mathrm{C}$ \\
$\mathrm{mg} / \mathrm{r} 000 \mathrm{kcal}$ & & \\
0.46 & 0.46 & 0.47 \\
0.46 & 0.47 & 0.48 \\
0.47 & 0.48 & 0.52 \\
0.46 & 0.47 & 0.50 \\
$\mathrm{mg} / \mathrm{x} 000 \mathrm{~N}$ N.F.C.* & & \\
0.74 & 0.75 & 0.77 \\
0.75 & 0.77 & 0.77 \\
0.77 & 0.79 & 0.84 \\
0.75 & 0.77 & $0.8 \mathrm{I}$ \\
$*$ Non-fat kcal. & &
\end{tabular}

Nicotinic acid

Although it has not been demonstrated conclusively that the requirement for nicotinic acid is a function of the energy turnover, the British Medical Association: Committee on Nutrition ( $195^{\circ}$ ) recommended that a pregnant woman should receive $4 \mathrm{mg} / 1000 \mathrm{kcal}$ daily. The (U.S.A.) National Research Council: Food and Nutrition Board (I953) specified the requirement for nicotinic acid to be ten times that for thiamine, which is in turn related to the calorie intake. Bro-Rasmussen $(1958 a, b)$ considers that a relationship with energy metabolism may be inferred from the functions of nicotinic acid.

The mean daily intakes of nicotinic acid in social classes $\mathrm{A}, \mathrm{B}$ and $\mathrm{C}$ were, respectively, $\mathrm{I} 2 \cdot 0, \mathrm{II}_{4} \cdot 4$ and $\mathrm{II} \cdot 6 \mathrm{mg}$. The first part of Table 9 shows the means per rooo kcal in each class, according to calorie intake. As with thiamine, the social-class gradient is reversed when the intakes are expressed in proportion to the calories provided by the diets, and it is so at each level of calorie intake. 
It is convenient to discuss thiamine and nicotinic acid together, since with both the social-class gradient in intakes becomes reversed when intakes are expressed relative to the calorie values of the diets. The supplies of thiamine and of nicotinic acid therefore were more often above standard in social class $\mathrm{C}$ than in class $\mathrm{A}$. In all classes, very few diets were 'deficient' according to the standards.

A quantitative analysis of the sources of thiamine and nicotinic acid in the foods taken by our subjects would be extremely laborious, and has not yet been attempted. Why the intakes of these vitamins tend to become relatively greater as the calorie values of the diets decrease therefore remains in doubt. Probably the explanation lies in a proportionately greater use of bread and other cereal products in the lower social

Table 9. Mean daily intakes of nicotinic acid and riboflavin by pregnant women ( $\mathrm{mg} / \mathrm{I} 000 \mathrm{kcal}$ ) according to social class and calorie value of the diets Daily calorie intake
(kcal)

2700 and over 2300-2700 Under 2300 All

2700 and over 2300-2700 Under 2300 All

\begin{tabular}{lll}
\multicolumn{3}{c}{ Social class } \\
A & B & C \\
Nicotinic acid & & \\
4.50 & 4.41 & 4.62 \\
4.43 & 4.40 & 4.86 \\
4.86 & 4.85 & 5.28 \\
4.57 & 4.55 & 5.01 \\
$\quad$ Riboflavin & & \\
0.79 & 0.72 & 0.72 \\
0.75 & 0.77 & 0.74 \\
0.80 & 0.77 & 0.76 \\
0.78 & 0.75 & 0.74
\end{tabular}

classes. More than half the thiamine and nicotinic acid in family diets comes from these foods and from meat, especially bacon (Ministry of Agriculture, Fisheries and Food, 1954). Wright (1958) has shown that the consumption of bread increases with diminishing socio-economic status.

It should be noted, in conclusion, that the nicotinic acid in cereals is nearly all 'bound' and probably not available to man (Braude, Kon, Mitchell \& Kodicek, 1955; Kodicek, Braude, Kon \& Mitchell, 1956). The physiological significance of the intakes reported here is therefore uncertain.

\section{Riboflavin}

The nature of the riboflavin requirement remained dubious until recently. The (U.S.A.) National Research Council: Food and Nutrition Board (I953) concluded that the requirement was related, not to the calorie requirement or to muscular activity, but to the protein requirement, and it made recommendations accordingly. On the other hand, the British Medical Association: Committee on Nutrition (1950), though recognizing that the evidence then available was 'hardly more than suggestive', recommended that adults, including pregnant women, should receive $0.6 \mathrm{mg} / 1000 \mathrm{kcal}$ daily. The review of Bro-Rasmussen (1958 $a, b$ ) has now shown beyond reasonable doubt that the optimum requirement of riboflavin is a function of the energy turnover; he considers the optimum requirement of a pregnant woman to be about $0.7 \mathrm{mg}$ / rooo kcal. 
In our subjects the mean daily intakes of riboflavin in social classes $\mathrm{A}, \mathrm{B}$ and $\mathrm{C}$ were $2 \cdot 05, \mathrm{I} \cdot 89$ and $\mathrm{I} \cdot 74 \mathrm{mg}$, respectively. The second part of Table 9 shows the means per $1000 \mathrm{kcal}$ in each class, according to calorie intake. The social-class gradient in intakes per $1000 \mathrm{kcal}$, which is present at each level of calorie intake, is less steep than that in total riboflavin intakes, but is in the same direction. In all groups, the mean intake exceeds Bro-Rasmussen's estimate of the requirement. The percentages of subjects in classes A, B and C taking less than $0.6 \mathrm{mg} / 1000 \mathrm{kcal}$ were, respectively, 8, 12 and I 5 , so that few were taking much less than the estimated optimum requirement.

\section{Ascorbic acid}

There appears to be no evidence that the requirement for ascorbic acid is related to the energy turnover and, since little is known of the metabolic functions of this vitamin, it is difficult to say on theoretical grounds whether such a relationship should or should not exist.

Table ı. Mean daily intakes of ascorbic acid by pregnant women ( $\mathrm{mg} / 1000 \mathrm{kcal}$ ) according to social class and calorie value of the diets

\begin{tabular}{lccc} 
Daily calorie intake & \multicolumn{3}{c}{ Social class } \\
\cline { 2 - 4 }$\quad$ (kcal) & A & B & C \\
2700 and over & 29 & 25 & 24 \\
$2300-2700$ & 28 & 25 & 25 \\
Under 2300 & 36 & 28 & 28 \\
All & 31 & 26 & 26
\end{tabular}

The mean intakes of ascorbic acid in social classes $\mathrm{A}, \mathrm{B}$ and $\mathrm{C}$ were, respectively, 79,66 and $6 \mathrm{r} \mathrm{mg}$ daily. Table ro gives the means per rooo kcal. The diets of low calorie value tended to have a relatively high ascorbic-acid content in all classes; and at each level of calorie intake social class $\mathrm{A}$ tended to take more vitamin $\mathrm{C}$ than other classes; there was little difference between classes $B$ and $\mathrm{C}$.

It has been pointed out previously (Thomson, 1958) that the estimated intakes of ascorbic acid must be regarded as tentative, and elaborate discussion of the present data is probably not worth while. The relatively high intakes of ascorbic acid in social class A reflect more extensive use of fruit and vegetables in the upper social classes. It also appears that, in all classes, increase of calorie intake is not accompanied by a commensurately increased intake of ascorbic acid. The interpretation of these findings in relation to requirements is difficult. None of the diets was likely to cause scurvy; whether any were likely to cause other possible manifestations of vitamin $\mathrm{C}$ deficiency remains an open question.

\section{Vitamin $A$}

The results of an analysis of vitamin $A$ intakes are not presented. Intakes of the vitamin varied very greatly between subjects but were, in general, high and probably adequate.

\section{GENERAL DISCUSSION}

In ordinary diets, the intakes of calories and of nutrients tend to rise and fall together. Therefore, a diet judged to be adequate in one respect is likely to be adequate in many 
other respects. Again, the requirement for certain nutrients is related to energy metabolism, so that a given intake of these nutrients is more likely to be 'adequate' if the calorie value of the diet is low.

With these considerations in mind, the findings in a dietary survey of primigravidae (Thomson, 1958) have been re-assessed. It appears that few, if any, of the subjects would be likely to show clinical evidence of deficiency of protein or the B vitamins. The same is true of vitamins A and C. Depending on the standard chosen, a high or fairly high proportion of subjects, especially in social class $\mathrm{C}$, was taking appreciably less than the estimated requirement for calcium; but, even with the most deficient diets, skeletal reserves should have been sufficient to protect mother and child against immediate harm.

Part of the social-class gradient in mean calorie intakes is accounted for by differences of body size, and the residual difference, about $200 \mathrm{kcal} /$ day between class $\mathrm{A}$ and class $\mathrm{C}$, may have been due to differences of activity. But in all classes there was a wide range of calorie intake, which may have been associated with differences in the amounts of weight gained during pregnancy and perhaps with certain abnormalities of pregnancy.

The steepness of the social-class gradient in nutritive values may have been underestimated, because reliable records were not obtained from a high proportion of subjects at the lower end of the social scale. In my opinion, however, this bias is not likely to make the intakes reported here seriously unrepresentative. Nor is it likely that the standards used in assessing the diets are too low. It seems justifiable to conclude that, in general, the diets were unlikely to induce specific deficiency states, at least during a first pregnancy. The obstetric histories of the subjects will be examined, and related to the diets, in the next paper of this series.

The description and evaluation of the data obtained in the Aberdeen dietary survey end at this point. But, because the conclusion just stated might be too narrowly interpreted, it is necessary also to sketch in the wider perspective of nutrition in relation to pregnancy.

Nutritional status in pregnancy does not depend only on the quality of the diet taken during pregnancy itself. Some women begin pregnancy well grown and healthy, thanks to a long history of satisfactory nutrition and a healthy way of life; such benefits are not likely to be seriously undermined by relatively slight deficiencies in the diet taken after pregnancy has started. Other women are stunted and lack physical vitality, probably owing to years of imperfect nutrition and unhealthy living; if their diets improve during pregnancy, it will undoubtedly be generally beneficial, but it would be unrealistic to expect a good diet, taken for the first time after pregnancy has started, to overcome completely the deleterious influence on reproductive efficiency of preexisting anatomical and physiological defects. It is impossible to specify the diets taken by our subjects during their growth and adolescence, or to tell whether there was much change of dietary habit following marriage and pregnancy. But the indirect evidence strongly supports the hypothesis that the nutritional history of many subjects had been imperfect; their physical health was impaired and their growth stunted; and the outcome was that their 'reproductive efficiency' (capacity for physiological 
childbearing) was limited in several important respects. I have already summarized some of the evidence (Thomson, 1957), and hope to report it in more detail later.

The diets measured in this survey were taken by women pregnant for the first time. The average nutritive value of family diets diminishes steadily with increasing family size (Ministry of Agriculture, Fisheries and Food, 1957) and this deterioration is likely to be more marked in the lower than in the upper social classes. Deterioration of the nutritive value of the mother's diet with increasing parity probably keeps pace with that of the family, which would accentuate any nutritional depletion caused by pregnancy and lactation. But the obstetric consequences will be largely masked by the great increase of reproductive efficiency present at least in a second and third pregnancy, compared with a first (Leitch, 1957). The effects of progressive malnutrition are therefore more likely to become manifest in the mother's general health and vitality than in her reproductive function. With grossly defective diets, pregnancy may precipitate a serious deficiency disease, such as osteomalacia, but such dramatic manifestations are now seldom seen in Britain.

The implications for health of the present dietary findings are therefore limited. The diets appear, in general, to have been compatible with a normal course and outcome of pregnancy. But it would not be justifiable to assume that the primigravidae studied were in a satisfactory state of nutrition when their pregnancies started, nor that a satisfactory state would be maintained through subsequent pregnancies.

\section{SUMMARY}

I. Correlations between levels of calories and nutrients in the diets taken by Aberdeen primigravidae during the years $195^{\circ}-3$ have been calculated. The results resemble those derived from the data of other surveys made in Britain about 20 years previously. Many of the coefficients of correlation are high, so that differences in the intakes of a given nutrient imply similar differences in other nutrients.

2. Part of the difference in the mean calorie intakes of subjects in three social classes is accounted for by differences of mean body size. When these differences of mean calorie intake are allowed for, the social-class gradient in the intakes of several nutrients disappears or is reversed.

3. In all social classes there is a wide range of calorie intake, which may be associated with differences of well-being during pregnancy.

4. Intakes of protein and of the $B$ vitamins appear to be generally adequate. The requirement for these nutrients is probably related to the calorie value of the diet.

5. Intakes of vitamins $\mathrm{A}$ and $\mathrm{C}$ appear also to be adequate.

6. Many subjects took less calcium than the estimated requirement for pregnancy; but the deficits were not large and immediately deleterious effects would not be expected.

7. The limitations of the data are discussed. Though the diets of these primigravidae appear to have been qualitatively adequate, it would be unjustifiable to conclude that the subjects were, and would remain, adequately nourished in all respects. 
I wish to thank Mr W. Z. Billewicz, statistician to the Obstetric Medicine Research Unit, for advice and assistance; Dr Isabella Leitch, Director of the Commonwealth Bureau of Animal Nutrition, for invaluable guidance; and the Secretary of State for Scotland, for a financial grant given on the recommendation of the Advisory Committee on Medical Research (Scotland).

\section{REFERENCES}

British Medical Association: Committee on Nutrition (1950). Report of the Committee on Nutrition. London: British Medical Association.

Braude, R., Kon, S. K., Mitchell, K. G. \& Kodicek, E. (1955). Lancet, 268, 898.

Bro-Rasmussen, F. (1958a). Nutr. Abstr. Rev. 28, r.

Bro-Rasmussen, F. (1958b). Nutr. Abstr. Rev. 28, 369 .

Cuthbertson, D. P. (1940-I). Nutr. Abstr. Rev. ro, I.

Dole, V. P. (1957). Amer. F. clin. Nutr. 5, 72.

Kodicek, E., Braude, R., Kon, S. K. \& Mitchell, K. G. (1956). Brit. F. Nutr. ro, 5 I.

Leitch, I. (1941-2). Nutr. Abstr. Rev. II, 509.

Leitch, I. (1957). In Combined Textbook of Obstetrics and Gynaecology, Chapter 6. [D. Baird, editor.] Edinburgh: Livingstone.

Leitch, I. \& Aitken, F. C. (1959). Nutr. Abstr. Rev. 29, 393.

McCance, R. A., Widdowson, E. M. \& Verdon-Roe, C. M. (1938). Y. Hyg., Camb., 38, 596.

Ministry of Agriculture, Fisheries and Food (1954). Domestic Food Consumption and Expenditure, 1952. London: H.M. Stationery Office.

Ministry of Agriculture, Fisheries and Food (1957). Domestic Food Consumption and Expenditure, 1955. London: H.M. Stationery Office.

National Research Council: Food and Nutrition Board (1953). Publ. nat. Res. Coun., Wash., no. 302.

Rowett Research Institute (1955). Family Diet and Health in Pre-war Britain. A Dietary and Clinical Survey. Dunfermline: Carnegie U.K. Trust.

Thomson, A. M. (1957). Proc. Nutr. Soc. 16, 45.

Thomson, A. M. (1958), Brit. F. Nutr. 12, 446 .

Thomson, A. M. \& Billewicz, W. Z. (1957). Brit. med. F. i, 243.

Wright, N. C. (1958). Roy. Soc. Health $\mathcal{7} .78,256$. 